\title{
Evaluation of the efficacies of selected antibiotics and medicinal plants on common bacterial fish pathogens
}

\author{
T. Rahman, M. M. R. Akanda ${ }^{1}$, M. M. Rahman ${ }^{2}$ and M. B. R. Chowdhury ${ }^{3}$ \\ Department of Aquaculture, Sylhet Agricultural University, Sylhet - 3100, Bangladesh \\ ${ }^{1}$ District Education Office, Kishorgonj - 2300, Bangladesh \\ ${ }^{2} \mathrm{D}$. Net Development Research Network, Dhaka - 1207, Bangladesh \\ ${ }^{3}$ Department of Aquaculture, Bangladesh Agricultural University, Mymensingh-2202, Bangladesh
}

\begin{abstract}
An experiment was conducted to compare the efficacies of some selected antibiotics and medicinal plants against common bacterial fish pathogens viz., Aeromonas hydrophila, Pseudomonas fluorescens and Edwardsiella tarda. Four different antibiotics viz., CFCIN (ciprofloxacin), Renamycin (oxytetracycline), DT-10 (doxycicline) and Sulfatrim (sulphadiazine + trimethoprim) were exposed in different doses (100, 75, 50 and 25 $\mathrm{ppm}$ ) to the culture of freshly isolated bacteria under the in vitro condition for sensitivity test and minimum inhibitory dose (MID) was determined. Based on in vitro results, antibiotics were applied to the experimental infection of Thai silver barb, Barbonymus gonionotus. CFCIN showed the best result with $100 \%$ recoveries of challenged fish in prolonged bath treatment. Medicinal plants were selected on the basis of previous studies. Crude extracts were prepared from various parts (leaves and bulb) of garlic, turmeric, akand and neem and four different doses were applied to the fresh culture of pathogenic isolates under the in-vitro condition to determine minimum inhibitory dose (MID). However, garlic offered the best result with $90.00 \pm 2.89 \%$ recoveries of challenged fish in aquarium trial. Akand + neem, turmeric and akand showed moderate to weak recovery rates with the same dose. The present study thus showed that medicinal plants would be an effective control measure along with antibiotics against bacterial fish diseases.
\end{abstract}

Keywords: Efficacy, Medicinal plants, Bacterial fish pathogens

\section{Introduction}

Bacteria, the major group of pathogens, pose one of the most significant threats to successful fish production throughout the world. Bacterial diseases are responsible for heavy mortalities in both culture and wild fishes throughout the world and most of the causative microorganisms are naturally occurring opportunist pathogens which invade the tissue of a fish host rendered susceptible to infection (Roberts, 1989). Among all other bacteria, Aeromonad, Pseudomonad and Edwardsiella tarda are the major bacterial fish pathogens which are widely distributed in aquatic organisms in nature (Banu, 1996 and Islam, 1996). In coastal regions, fish have been suffered from vibriosis, a bacterial disease causing losses in the fish production (Rahman, 2005).

Control of fish disease is currently based almost entirely on chemotherapy and it will entirely retain a role in the management of fish culture systems (Roberts, 1995). Anti-bacterial chemotherapy has been applied in aquaculture for over 50 years (Inglis, 1996). Antibiotics are also used prophylactically in carp culture at times of year when haemorrhagic septicaemia is most likely to occur (Inglis et al., 1994). But habitual use of anti-bacterials can lead to problems with bacterial resistance and unacceptable residues in aquaculture products and environment. The resistant bacterial strains could have a negative impact on the therapy of fish diseases or human diseases and environment of fish farms (Smith et al., 1994). This situation actually brings human to new medical dilemma (Muniruzzaman and Chowdhury, 2004). Medicinal plants possess therapeutic properties; exert beneficial pharmacological effects on the animal body, widely available in nature and eco-friendly. A scientific study to investigate the antibacterial activity of the medicinal plants, guava (Psidium guajava) against bacteria pathogenic for shrimp was initiated by Direkbusarakom and Aekpanithanpong (1992). Kraus (1995) found that extract of neem fruit, seeds, seed kernel, twigs, stem bark and root have fungicidal and bactericidal properties. Externally garlic (Allium sativum) is used as disinfectant and it is applied to indolent tumours, ulcerated surface and wounds (Dastur, 1977). Chowdhury et al. (1991) reported that extract obtained from garlic was also highly effective against two tested bacteria, $A$. hydrophila and P. fluorescens (MIC $0.6 \mathrm{mg} / \mathrm{ml}$ ). Garlic, turmeric, akand and neem could be used as an alternative therapeutic measure against bacterial infection of fish (Rahman, 2005). But sporadic findings from the previous studies could not satisfy a suitable prevention and control measures. 
Considering the above aspects, the present study was conducted to suggest a package in favour of proper health management in the aquaculture of Bangladesh by comparing the efficacies of selected antibiotics and medicinal plants on common bacterial fish pathogens.

\section{Materials and Methods}

\section{Selection of Pathogens}

Suspected pathogens were isolated from diseased wild and farmed fishes for using in present studies. Methods of bacterial isolation, their characterization and pathogenicity test were completed according to the method described by Barrow and Feltham (1993) and Chowdhury and Muniruzzaman (2002). Finally, high virulent species viz., Aeromonas hydrophila (TL-2), Pseudomonas fluorescens (AK-2) and Edwardsiella tarda (PL-1) were identified upto species level based on their biochemical characters and compared with old laboratory stocks and selected for further studies.

\section{Selection of antibiotics}

In the aquaculture of Bangladesh, locally available veterinary grade antibiotics are used for the prophylaxis and treatment of fish disease problems. Based on preliminary investigation, availability in markets and reports of the previous workers, four available antibiotics viz., CFCIN (Ciprofloxacin 10\%; FnF) Renamycin (Oxytetracyclin, USP 200 mg; Renata Ltd.), DT-10 (Doxycicline 10\% + Trimethoprime 10\%; FnF) and Sulfatrim (Sulphadiazine BP 40\% + Trimethoprim BP 8\%; Techno Drugs) were selected for this study.

\section{Selection of Medicinal Plants and Extracts Preparation}

Primarily, fifteen medicinal plants were selected based on their recognized medicinal properties described by Dastur (1977) and Anawer (2001) and the previous studies conducted by Muniruzzaman and Chowdhury (2004) and Rahman (2005). Among these, most effective garlic (A. sativum), turmeric (Curcuma longa), Akand (C. gigentia) and mixed extracts of Akand + Neem (C. gigentia $+A$. indica) were selected for the present studies. Most of the medicinal plants were collected from the adjacent area of Bangladesh Agricultural University, Mymensingh.

Desired parts of plants were washed with clean water, rinsed with sterilized distilled water and cut into small pieces. Before making crude extract, each medicinal plant was weighed and then paste was prepared using stone made homogenizer. Fibrous particulates from the extracts were screened out by pressing through fine meshed cotton cloth and finally filtered through Whatman 541 filter paper to get fine extracts. Crude extracts were then collected in conical flasks and preserved into refrigerator at low temperature of $10^{\circ} \mathrm{C}$ to use in future under the laboratory condition.

\section{In-vitro Efficacy Test}

Suspensions of freshly cultured bacterial isolates were prepared at the concentration of $2.5 \times 10^{7}$ CFU/ml by following agar plate dilution method. $0.1 \mathrm{ml}$ of each bacterial suspension was spread over Tryptone Soya Agar (TSA, Oxoid) plates using a sterilized glass rod. Fifty $\mu \mathrm{l}$ of testing agents were inoculated separately at pre-fixed doses on the sterile disc of blotting paper ( $3 \mathrm{~mm}$ diameter), dispensed earlier on the culture plates.

\section{a. Antibiotic sensitivity test}

Effects of selected antibiotics were determined by antibiotic sensitivity test using drug disc (paper disc) method against the most virulent bacterial isolates. Due to unavailability of different antimicrobiotic discs, selected antibiotics were diluted in four different concentrations viz., 25, 50, 75, $100 \mathrm{ppm}$ and $50 \mu \mathrm{l}$ was dropped on each blotting paper (3 $\mathrm{mm}$ in diameter) disc and incubated for 5 days at $20^{\circ} \mathrm{C}$. Sensitivity was recognized with clear zone surrounding the disc. The diameters of the restricted halos around the paper disc were measured time to time for determining the minimum inhibitory dose (MID). Selected antibiotics with their varied doses are illustrated in Table 1. 
Table 1. Selected antibiotics and their varied doses applied on bacterial isolates

\begin{tabular}{|c|c|c|c|}
\hline \multirow[b]{2}{*}{ SI. No. } & \multicolumn{2}{|c|}{ Name of antibiotics } & \multirow[t]{2}{*}{ Doses } \\
\hline & Trade name & Type of antibiotics & \\
\hline \multirow{4}{*}{1.} & \multirow{4}{*}{ CFCIN } & \multirow{4}{*}{ Ciprofloxacin } & $25 \mathrm{ppm}$ \\
\hline & & & 50 ppm \\
\hline & & & 75 ppm \\
\hline & & & $100 \mathrm{ppm}$ \\
\hline \multirow{4}{*}{2.} & \multirow{4}{*}{ Renamycin } & \multirow{4}{*}{ Oxytetracyclin } & $25 \mathrm{ppm}$ \\
\hline & & & 50 ppm \\
\hline & & & 75 ppm \\
\hline & & & $100 \mathrm{ppm}$ \\
\hline \multirow{4}{*}{3.} & \multirow{4}{*}{ DT-10 } & \multirow{4}{*}{ Doxycicline } & $25 \mathrm{ppm}$ \\
\hline & & & $50 \mathrm{ppm}$ \\
\hline & & & $75 \mathrm{ppm}$ \\
\hline & & & $100 \mathrm{ppm}$ \\
\hline \multirow{4}{*}{4.} & \multirow{4}{*}{ Sulfatrim } & \multirow{4}{*}{$\begin{array}{c}\text { Sulphadiazine } \\
+ \\
\text { Trimethoprim }\end{array}$} & $25 \mathrm{ppm}$ \\
\hline & & & $50 \mathrm{ppm}$ \\
\hline & & & $75 \mathrm{ppm}$ \\
\hline & & & $100 \mathrm{ppm}$ \\
\hline
\end{tabular}

\section{b. Efficacy test with medicinal plants}

Based on our previous study (Muniruzzaman and Chowdhury, 2004), extracts of different plants were applied on the fresh culture of the three bacterial isolates (Aeromonas hydrophila, Pseudomonas fluorescens and Edwardsiella tarda sp.) for in-vitro efficacy test at pre-fixed doses viz., 2, 4, 6 and 8 $\mathrm{mg} / \mathrm{ml}$ (Table 2). The microbial growth inhibition status was graded as strong, moderate, poor and not effective by comparing with the control ones to different doses and inhibitory performance was detected.

Table 2. Various doses of selected medicinal plants applied on pathogenic bacterial isolates

\begin{tabular}{|c|c|c|}
\hline SI. No. & Name of medicinal plants & Doses \\
\hline \multirow{4}{*}{1.} & \multirow{4}{*}{ Garlic (Bulb) } & $2 \mathrm{mg} / \mathrm{ml}$ \\
\hline & & $4 \mathrm{mg} / \mathrm{ml}$ \\
\hline & & $6 \mathrm{mg} / \mathrm{ml}$ \\
\hline & & $8 \mathrm{mg} / \mathrm{ml}$ \\
\hline \multirow{4}{*}{2.} & \multirow{4}{*}{ Turmeric (Bulb) } & $2 \mathrm{mg} / \mathrm{ml}$ \\
\hline & & $4 \mathrm{mg} / \mathrm{ml}$ \\
\hline & & $6 \mathrm{mg} / \mathrm{ml}$ \\
\hline & & $8 \mathrm{mg} / \mathrm{ml}$ \\
\hline \multirow{4}{*}{3.} & \multirow{4}{*}{ Akand (Leaf) } & $2 \mathrm{mg} / \mathrm{ml}$ \\
\hline & & $4 \mathrm{mg} / \mathrm{ml}$ \\
\hline & & $6 \mathrm{mg} / \mathrm{ml}$ \\
\hline & & $8 \mathrm{mg} / \mathrm{ml}$ \\
\hline \multirow{4}{*}{4.} & \multirow{4}{*}{ Akand (Leaf) + Neem (Leaf) } & $2 \mathrm{mg} / \mathrm{ml}$ \\
\hline & & $4 \mathrm{mg} / \mathrm{ml}$ \\
\hline & & $6 \mathrm{mg} / \mathrm{ml}$ \\
\hline & & $8 \mathrm{mg} / \mathrm{ml}$ \\
\hline
\end{tabular}

\section{Investigation on the Therapeutic Effects (In-vivo)}

Preparation of bacterial suspension and injection: Selected bacterial isolates (TL-2, AK-1 and PL2) were cultured on TSA, inoculation was done carefully and incubated at $22^{\circ} \mathrm{C}$ for $18-24$ hours. Around $25 \mathrm{mg}$ of bacterial colonies were weighed to make homogenous solution with $10 \mathrm{ml}$ of $0.85 \%$ sterile physiological saline in a vial using auto vortex machine. To obtain the expected concentration $\left(3 \times 10^{7} \mathrm{CFU} / \mathrm{ml}\right.$ ) of bacterial suspension, decimal dilution technique of the stock solution was applied and made it ready for injection. 
Healthy young Thai silver barb (Barbonymus gonionotus) weighing 15 to $20 \mathrm{gm}$, were injected smoothly and carefully with $1.0 \mathrm{ml}$ disposable syringes at a dose of $0.1 \mathrm{ml} / \mathrm{fish}$ comprising $3 \times 10^{7}$ $\mathrm{CFU} / \mathrm{ml}$ with the suspensions of three pre-selected pathogenic bacterial isolates. The experimental infection of the injected fish was expressed as lesion on fins, skin, head or body surface. Three replications were used for each test.

\section{a. Effects of antibiotics on bacterial infection}

After experimental infection with virulent isolates, selected antibiotics were applied individually to a group of ten strong and disease free fish to observe their effects. The treatments selected for this purpose were $T_{1}$ with CFCIN, $T_{2}$ with Renamycin, $T_{3}$ with DT-10, $T_{4}$ with Sulfatrim and $T_{5}$ as control. Prolonged bath treatment was applied separately for about 3-4 hours and twice per day. Temperature was maintained by room temperature and dissolved oxygen was ensured by regular aeration.

\section{b. Therapeutic effects of medicinal plants}

Immediately after injection, fishes were exposed for treatment trial into four plant extracts viz., garlic $\left(T_{1}\right)$, turmeric $\left(T_{2}\right)$, akand $\left(T_{3}\right)$ and extracts of neem + akand $\left(T_{4}\right)$, mixed earlier with five litres of settled tap water in four small aquaria. Another aquarium was set as control $\left(T_{5}\right)$ without mixing any plants extract. Dip bath treatment was performed up to the tolerance level of fish at the selected dose of $8 \mathrm{mg} / \mathrm{ml}$ for twice a day. The whole process was continued up to 10 days. Fish were observed for pathological change, moribund condition and subsequent healing process owing to herbal treatment.

The analysis of data was done following one way analysis of variance (ANOVA) using MSTAT programme. The mean differences among the treatments were adjudged with Duncan's Multiple Range Test (Gomez and Gomez, 1984).

\section{Results and Discussion}

Effect of different antibiotics on the fish pathogenic bacteria under laboratory condition provided useful information for treatment of bacterial fish diseases. Antibiotic sensitivity test of each pathogenic species was performed under in-vitro condition to determine minimum inhibitory dose (MID). All tested isolates (100\%) were sensitive to CFCIN followed by Renamycin (86.67\%) at $75 \mathrm{ppm}$. DT-10 was not so effective in lower concentration but sensitive for $80 \%$ isolates at $100 \mathrm{ppm}$. Moreover, only $53.33 \%$ pathogens were sensitive in case of salfatrim at $100 \mathrm{ppm}$. After investigation on 106 (out of 132) mesophilic aeromonads Yucel, et al., (2005) found that all strains (A. hydrophila, A. veroni bv. sobria, A. caviae) were susceptible to ciprofloxacin. Wolska et al., (1999) also reported that $99 \%$ of Pseudomonas aeruginosa strains were susceptible to ciprofloxacin. Sarker et al. (2000) performed drug sensitivity test and found that $50 \%$ of the Aeromonas sobria isolates were highly sensitive to oxytetracycline, oxolinic acid and chloramphonical and resistant to erythromycin and sulphamethoxazole.

Therapeutic effects of the antibiotics tested were examined through experimental infection. Best result was obtained with $100 \%$ recovery (Table 3 ) of infected fish when the antibiotic, CFCIN was used for prolonged bath treatment in laboratory condition. Renamycin was also found to be effective in healing bacterial infection $(90.00 \pm 2.89 \%)$ followed by DT-10 (80.00 $\pm 5.78 \%)$. Sulfatrim was detected as less effective with $60.00 \pm 4.62 \%$ recoveries of challenged fish. Kou et al. (1988) and Liao et al. (1996) used oxytetracycline in aquaculture as bactericide. Lio-Po and Sanvictores (1987) found positive effect of oxytetracycline in controlling Pseudomonas sp. in Tilapia fry. According to Shariff et al., (1996) oxytetracycline (about $20 \mathrm{ppm}$ ) in a dip or bath solution is used against bacterial disease in Malaysia and Singapore. Chowdhury et al. (2003) found positive effect of Renamycin (oxytetracycline) against bacterial infection.

Recovery rate of experimentally infected fish varied with the concentration of extracts and species of the medicinal plants. Best result was obtained in the case of garlic $\left(T_{1}\right)$ at the concentration of $8 \mathrm{mg} / \mathrm{ml}$ where recovery rate was significantly $(p<0.05)$ higher $(90.00 \% \pm 2.89)$ (Table 4) than all other treatments performed within the 10 days of experimental period. The extract obtained from turmeric $\left(T_{2}\right)$ was medium effective $\left(60.00 \% \pm 4.62\right.$ recovery rate) but lower effect was found in the case of $T_{3}$, where $50.00 \% \pm 2.89$ of the infected fish were recovered by the extract of akand. Moreover, mixture of 
akand + neem showed the prominent effect with $80.00 \% \pm 5.78$ recovery rate against the infectivity of bacterial pathogens which was ultimately suited with the previous studies conducted by Rahman (2005). The study also revealed that the pathological changes have an inverse relation with the efficacy of the treatments.

Table 3. The effect of antibiotics on experimentally infected fish with bacterial pathogens

\begin{tabular}{|l|c|c|}
\hline \multicolumn{1}{|c|}{ Treatment } & Dose $(\mathrm{mg} / \mathrm{l})$ & Recovery $(\%)$ \\
\hline $\mathrm{T}_{1:}$ CFCIN & 75 & $100.00^{\mathrm{a}} \pm 0.00$ \\
\hline $\mathrm{T}_{2:}$ Renamycin & 75 & $90.00^{\mathrm{b}} \pm 2.89$ \\
\hline $\mathrm{T}_{3:}$ DT-10 & 100 & $80.00^{\mathrm{c}} \pm 5.78$ \\
\hline $\mathrm{T}_{4:}$ Sulfatrim & 100 & $60.00^{\mathrm{e}} \pm 4.62$ \\
\hline $\mathrm{T}_{5:}$ Control & No dose & $0^{\mathrm{h}}$ \\
\hline Level of significance & - & ${ }^{\mathrm{h}}$ \\
\hline
\end{tabular}

Values bearing different superscripts $(a, b, c, d, e, f, g, h)$ in the same column are significantly different but with the same superscripts are not significantly different $(p<0.05)$

** : Significant $(p<0.05)$

Recovery (\%): Mean \pm S.E.

Table 4. The effect of medicinal plants on experimentally infected fish with bacterial pathogens

\begin{tabular}{|l|c|c|}
\hline \multicolumn{1}{|c|}{ Treatment } & Dose $(\mathrm{mg} / \mathrm{ml})$ & Recovery (\%) \\
\hline $\mathrm{T}_{1:}$ Garlic (A. sativum) & 8 & $90.00^{\mathrm{a}} \pm 2.89$ \\
\hline $\mathrm{T}_{2:}$ Turmeric (C. longa) & 8 & $60.00^{\mathrm{C}} \pm 4.62$ \\
\hline $\mathrm{T}_{3:}$ Akand (C. gigentia) & 8 & $50.00^{\mathrm{d}} \pm 2.89$ \\
\hline $\mathrm{T}_{4:}$ Akand + Neem (C. gigentia + A. indica) & 8 & $80.00^{\mathrm{b}} \pm 5.78$ \\
\hline $\mathrm{T}_{5:}$ Control & No extract & $0^{\mathrm{e}}$ \\
\hline Level of significance & - & ${ }^{*}$ \\
\hline
\end{tabular}

Values bearing different superscripts $(a, b, a b, c, d, e)$ in the same column are significantly different but with the same superscripts are not significantly different $(p<0.05)$

** : Significant $(p<0.05)$

Recovery (\%): Mean \pm S.E.

The bulbs of $A$. sativum are used both for medicinal and culinary purposes (Villachira, 1998). The bulbs contain an acrid volatile oil (0.25\%), starch, mucilage, albumin and sugar. The major component of volatile oil is propyl disulphide which is a powerful germicide (Anawer, 2001). Garlic or onion has been mixed to the shrimp pellet and fed every day to protect the bacterial infection (Direkbusarakom, 2000). Akand is used as a traditional medicinal plant with unique properties (Oudhia and Tripathi, 1998). The extract of akand contains several proteinases as well as calotropin and other cardiac glycosides. A powder of dried leaves of akand is an efficacious local application for ulcer, eczema and other skin diseases (Anawer, 2001). Crude extract of different parts of neem have been used as traditional medicine for treatment of various diseases (Biswas et al., 2002).

In aquarium trial, use of antibiotics took quickest possible of time (seven days only) rather than medicinal plants to recover the experimental infection. However, findings of the present studies provided useful information (regarding the application of antibiotics medicinal plants) for making a package in favour of proper fish health management. Detailed studies on field trial are necessary to establish the facts.

\section{References}

Anawer, M. (ed.). 2001. Vesoj Udvider Homeophathic Baboher: Bangladesh Prakhit (Homeopathic uses of medicinal plants; Bangladesh perspective). Published by text book division, Bangla Academy, Dhaka-1000, Bangladesh. 545 pp.

Aoki, T. 1992. Chemotherapy and drug resistance in fish farms in Japan. In: Diseases in Asian Aquaculture I. Proceedings of the first symposium on diseases in Asian aquaculture, 26-29 Novemeber 1990, in Indonesia. Shariff, M. R.P. Subasinghe, J.R. Arthur (eds.). Fish Health Section, Asian Fisheries Society, Manila, Philippines. pp. 519-529. 
Banu, G.R. 1996. Studies on the bacteria Aeromonas spp. in farmed fish and water in Mymensingh region. An M.S. Thesis, submitted to the Department of Fisheries Biology and Limnology, Faculty of Fisheries, Bangladesh Agricultural University, Mymensingh, Bangladesh. 95 pp..

Biswas, K., Chattopadhyay, I., Banerjee, R.K. and Bandyopadhyay, U. 2002. Biological activities and medicinal properties of neem (Azadirachta indica), Curr. Sci., 82 (11): 1336-1345.

Chowdhury, A.K., Ahsan, M. Islam, S.N. and Ahmed, Z.U. 1991. Efficacy of aqueous extract of garlic and allicin in experimental shigellosis in rabbits. Indian J. Med. Res., 93: 6-33.

Chowdhury, M.B.R., Muniruzzaman, M., Zahura, U.A., Habib, K.Z. and Khatun, M.D. 2003. Ulcer type of disease in the fishes of small-scale farmer's pond in Bangladesh. Pakistan J. Biol. Sci., 6 (6): 544-550.

Dastur, J. F. (ed.). 1977. Medicinal plants of India and Pakistan. Published by D.B. Taraporevala Sons \& Co. Private Ltd., 210, Dr. Dadabhai Naorojii Road, Bombay 400 001, 201pp.

Direkbusarakom, S. and Aekpanithanpong, U. 1992. The efficacy of the crude extract from the leaf of guava (Psidium guajava L.) on Vibrio spp. isolated from diseases tiger prawn (Penaeus monodon). In: Proceedings of the Seminar on Fisheries, Department of Fisheries. pp. 259-262.

Gomez, K.A. and Gomez, A.A. 1984. Statistical Procedure for Agricultural research. Int. Rice Res. Inst. John Wiley and Sons, New York, Chickester, Brisbane, Toronto, Singapore, pp. 139-240.

Inglis, V. 1996. Antibacterial chemotherapy in aquaculture: review of practice, associated risks and need for action. In: Use of Chemicals in Aquaculture in Asia. Arthur, J. R., C. R. Lavilla-Pitogo and R. P. Subasinghe (eds.). Southeast Asian Fisheries Development Centre, Aquaculture Department Tigbauan, Iloilo, Philippines. pp. 7-22.

Inglis, V., Roberts, R.J. and Bromage, N.R. (eds.). 1994. Bacterial diseases of fish. Blackwell Science Ltd., London, 312 pp.

Islam, M.S. 1996. Studies on the bacteria Pseudomonas spp. in farmed fishes and in water around Mymensingh. An M.S. Thesis, submitted to the Department of Fisheries Biology and Limnology, Bangladesh Agricultural University, Mymensingh. 80 pp.

Kou, G.H., Liu, C.I. and Liu, C.K. 1988. Handbook of Fish Disease. Pig Research Institute, Taiwan, Miaoli, 129 pp.

Kraus, W. 1995. Azadirachtin and other triterpenoids, Biologically Active Ingredients In: Schmutterer, H. (ed.). The Neem Trees, VCH Publishers Inc., New York, USA. Chapter 2, pp. 35-73.

Liao, I.C., Lee, K.K. and Chien, Y.H. 1996. Practical approaches to marine fish health problems in Taiwan. In: Main, K. L. and C. Rosenfeld, (eds.). Aquaculture Health Management Strategies for Marine Fish in Asia and the United States. pp. 57-67.

Lio-Po, G.D. and Sanvictores, M.E.G. 1987. Studies on the causative organism of Oreochromis niloticus (Linnaeus) fry mortalities I. Primary isolation and pathogenicity experiments. J. Aquacult. Trop., 2: 25-30.

Muniruzzaman, M. 2004. Etiopathology and control measures of ulcer diseases in the cultured fishes of Bangladesh. A Ph. D. Thesis, submitted to the Department of Aquaculture, Bangladesh Agricultural University, Mymensingh, Bangladesh. $302 \mathrm{pp}$.

Muniruzzaman, M. and Chowdhury, M. B. R. 2004. Sensitivity of fish pathogenic bacterial to various medicinal herbs. Bangladesh J. Vet. Med., 2 (1): 75-82.

Oudhia, P. and Tripathi, R.S. 1998. Proc. National Conference on Health Care and Development of Herbal Medicines, IGAU, Raipur, India 29-30 August, 1997. pp. 71-78.

Rahman, M. M. 2005. Efficacy of medicinal plants against bacterial fish pathogens. An M.S. Thesis, submitted to the Department of Aquaculture, Bangladesh Agricultural University, Mymensingh, Bangladesh. 73 pp.

Roberts, R. J. 1989. Fish Pathology ( $2^{\text {nd }}$ Ed.). Bailliene Tindall, London. 469 pp.

Roberts, R. J. 1995. Aquatic animal health towards. 2000. In: Diseases in Asian Aquaculture II. Shariff, M., T. R. Arthur, R. P. Subasinghe (eds.). Fish Health Section, Asian Fisheries Society, Manila. pp. 3-7.

Sarker, M. A., Uddin, M. N., Sarker, M. G. A. and Chowdhury, M. B. R. 2000. Pathogenicity of Aeromonas sobria to Thai silver barb (Barbodes gonionotus Bleeker) and its sensitivity to some antibiotic agents. Bangladesh. J. Fish. Res., 4 (2): 165-170.

Sarker, M. G. A. 2000. Activities of Aeromonas bacteria and Aphanomyces fungus causing EUS in fresh water fishes of Bangladesh. An M.S. Thesis, Department of Aquaculture, Bangladesh Agricultural University, Mymensingh, 93 pp.

Shariff, M., Nagaraj, G., Chua, F. H. C. and Wang, Y. G. 1996. The use of chemicals in Aquaculture in Malaysia and Singapore, pp. 127-140.

Smith, P., Heny, M. P. and Samuelsen, S. B. 1994. Bacterial resistance to antimicrobial agent used in fish farming: a critical evaluation of method and meaning. Annual Review of Fish Diseases, 4: 273-313.

Vallachira, A. 1998. Veterinary Materia Medica. First edition. Jaypee Brothers Medical Publishers (P) Ltd. B-3 EMCA House, 23/23 B Ansari Road, Daryagonj, Post Box 7193, New Delhi 110002, India. 229 pp.

Wolska, K, Jakubczak, A., Anusz, Z. and Bukowski K. 1999. Susceptibility of Pseudomonas aeruginosa strains to antibiotics and chemotherapy. Medycyna Weterynaryjna. 55 (12): 812-817.

Yucel, N, AsIm, B. and Beyatl, Y. 2005. Prevalence and resistance to antibiotics for Aeromonas species isolated from retail fish in Turkey. J. Food Quality, 28 (4): 313-324. 